\title{
New Malthodes (Insecta: Cantharidae: Coleoptera) from the Rovno Amber (Upper Eocene of Ukraine)
}

\section{Новый Maltbodes (Insecta: Cantharidae: Coleoptera) из ровенского янтаря (Верхний Эоџен Украины)}

\author{
Sergey V. Kazantsev \\ C.В. Казанцев
}

Donetskaya 13-326, Moscow 109651, Russia. E-mail: kazantss@mail.ru Россия, 109651 Москва, ул. Донецкая 13-326.

KEY WORDS: Coleoptera, Cantharidae, Malthininae, new species, amber, palaeontology, Eocene, Ukraine. КЛЮЧЕВЫЕ СЛОВА: Coleoptera, Cantharidae, Malthininae, новый вид, янтарь, палеонтология, эоцен, Украина.

ABSTRACT. A new fossil species, Malthodes perkovskyi sp.n., is described from the Rovno amber. The new species appears to be close to some of its recent congenerics from the Far East.

РЕЗЮМЕ. Из ровенского янтаря описывается новый ископаемый вид, Malthodes perkovskyi sp.n. Новый вид, по всей очевидности, близок к некоторым рецентным представителям рода с Дальнего Востока.

\section{Introduction}

So far only one fossil species of the cantharid genus Malthodes Kiesenwetter, 1852 distributed almost worldwide was known. It is Malthodes obtusus Foerster, 1891, described from the Brunstatt brown coals of Alsace [Foerster, 1891]. Unidentified Malthodes species were later signaled from the Baltic amber [Klebs, 1910; Hieke \& Pietrzeniuk, 1984]. The Rovno amber also yielded a fossil soldier beetle belonging to this genus, a well preserved and clearly observable male specimen found to represent a new species, presumably close to some of its recent congenerics from the Far East.

\section{Material and Methods}

The amber specimen with the insect inclusion was polished at its two sides allowing best dorsal and ventral views of the included beetle. For examination and preparing the illustration MSP-1 stereo dissecting microscope with $8 x-80 x$ magnification range was used.

\section{Taxonomy}

Malthodes perkovskyi Kazantsev, sp.n. Figs 1-3

MATERIAL: Holotype, $0^{7}$, specimen No. K-4579, Klesov, Rovno amber, Upper Eocene (Schmalhausen Institute of Zoology, Kiev).

DESCRIPTION. Male. Dark brown to black; pronotum lighter with black W-sign; elytra with lighter disc and yellow spots near apices.

Head triangular. Eyes small, interocular dorsal distance ca. 3.7 times greater than eye radius. Terminal palpomeres distally pointed, roundish, ca. twice as long as wide. Antennae filiform, attaining to elytral apices, with antennomere 3 1.4 times longer than pedicel (antennomere 2) and 1.1 times shorter than antennomere 4 (Fig. 1); pubescence erect, relatively long.

Pronotum transverse, ca. 1.1 times as wide as long, mildly convex basally, slightly diverging anteriorly, margined throughout, with noticeable anterior and posterior angles. Scutellum triangular, rounded at apex (Fig. 1).

Elytra elongate, 2.5 times as long as wide at humeri, shortened, attaining to ca. half of abdomen, slightly narrowing distally (Fig. 1); with obscure traces of oblique longitudinal costae; apices somewhat swollen.

Legs slender, tibiae straight, subequal in length to femurs, tarsi narrow, tarsomeres 1-3 without plantar pad (Fig. 2).

Terminal ventrite elongate, almost parallel-sided, with broad rectangular distal incision; penultimate tergite elongate, slightly constricted distally, with unmodified sides, ultimate tergite elongate, parallel-sided, with triangular distal incision (Fig. 3).

Length (from anterior head margin to end of abdomen): $3.4 \mathrm{~mm}$. Width (humerally): $0.6 \mathrm{~mm}$.

Female. Unknown.

ETYMOLOGY. The new species is named after Dr. E. Perkovskij, curator of the Rovno amber beetles collection at the Schmalhausen Institute in Kiev. 


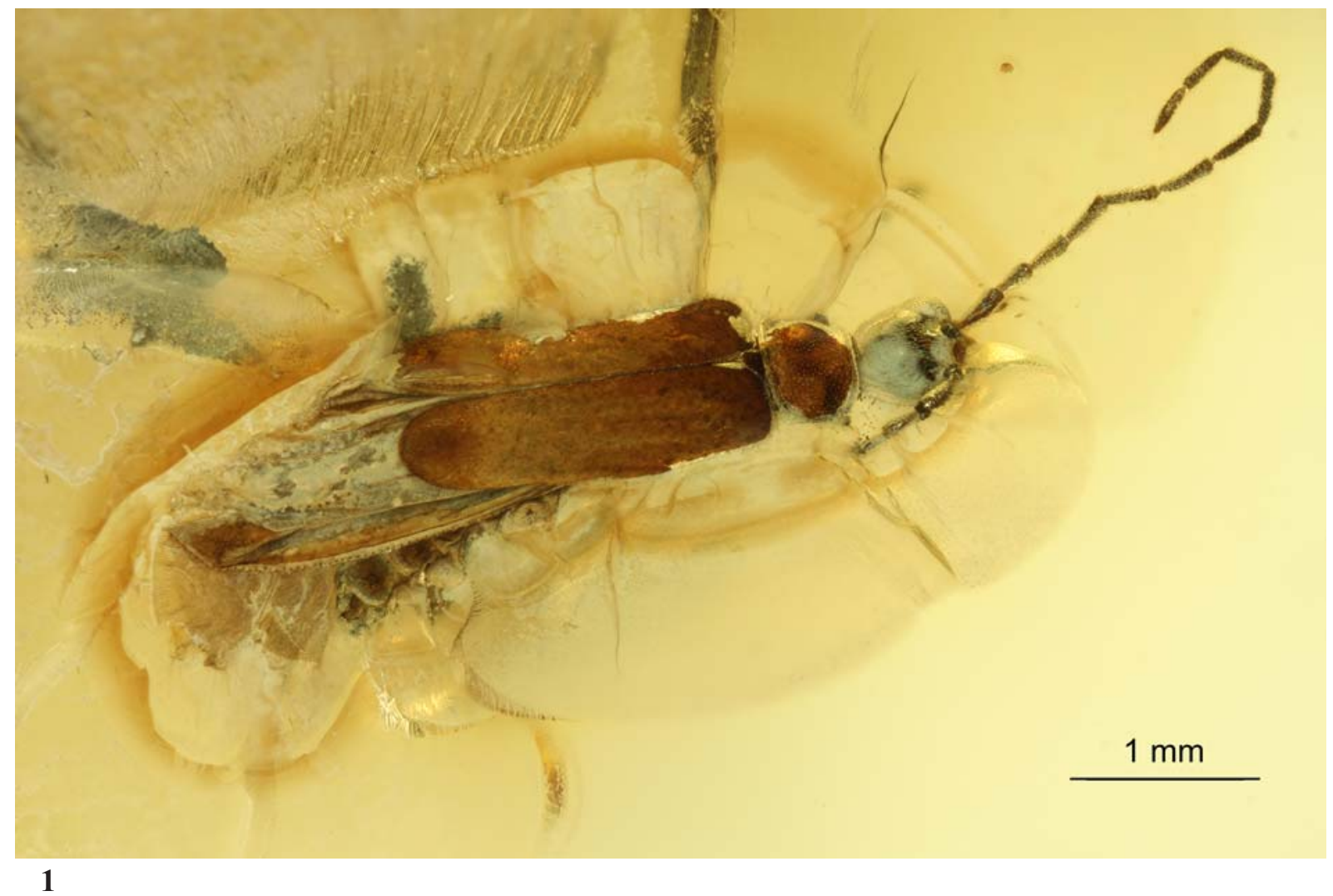

1

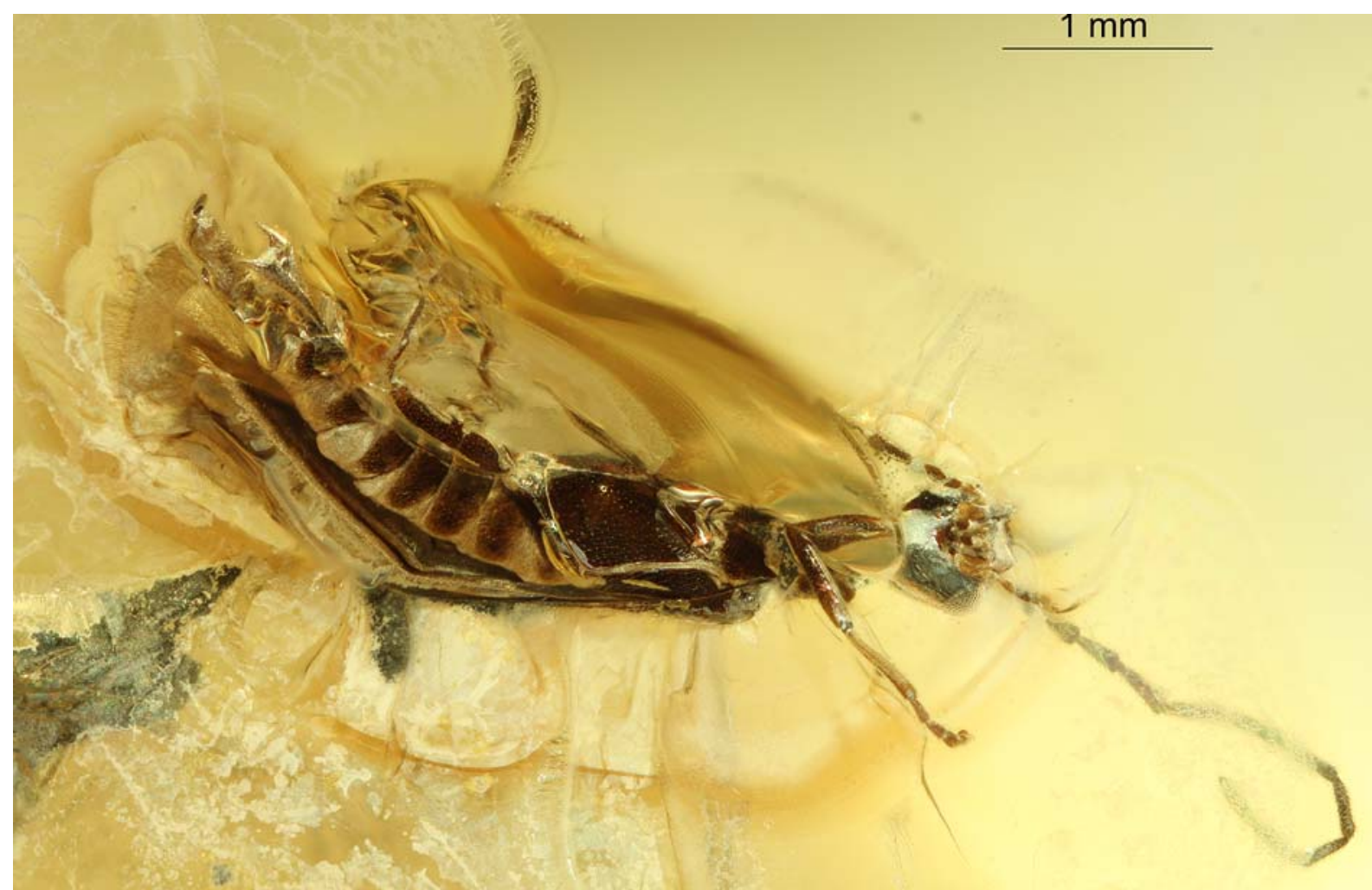

2

Figs 1-2. Malthodes perkovskyi sp.n., general view of holotype male: 1 - dorsally; 2 - ventrally .

Pис. 1-2. Malthodes perkovskyi sp.n., общий вид голотипа, самец: 1 - сверху; 2 - снизу. 
REMARKS. The Holotype was found in a 15.5 gram piece of Rovno amber.

DIAGNOSIS. Malthodes perkovskyi sp.n. appears to be related to M. kurosawai Wittmer, 1954 and M. kerzhneri Wittmer, 1979 [Wittmer, 1954, 1979], occurring in Japan and southern Kurils, also with relatively short pedicel, completely margined pronotum and little modified terminal abdominal segments, differing by the more elongate and parallel-sided ultimate tergite and more distally incised ultimate sternite (Fig. 3).

ACKNOWLEDGEMENTS. It is my pleasant duty to express gratitude to Dr. E. Perkovsky (Kiev) for the possibility to study the Cantharidae of the Rovno amber collection at the Schmalhausen Institute in Kiev. My special thanks are due to Prof. K.V. Makarov (Moscow) for his kind help with the photos of Malthodes perkovskyi sp.n.

\section{References}

Foerster B. 1891. Die Insekten des "Plattigen Steinmergels" von Brunstatt // Abh. Geol. Spez.-Karte Elsass-Lotharingen. Bd.3. S.333-594.

Klebs R. 1910. Über Bernstein einschlusse im allgemeinen und die Coleopteren meiner Bersteinsammlung // Schr. Phys.-okon. Ges. Königsberg. Bd.51. Hf.3. S.217-242.

Hieke F. \& Pietrzeniuk E. 1984. Die Bernstein-Käfer des Museums für Naturkunde, Berlin (Insecta, Coleoptera) // Mitt. Zool Museum Berlin. Bd.60. Hf.2. S.297-326.

Wittmer W. 1954. Zur Kenntnis der Malthodes Japans (Coleoptera, Cantharidae). 18. Beitrag zur Kenntnis der palaearktischen Malacodermata // Mushi. Vol.26. No.9. P.47-52.

Wittmer W. 1979. 64. Beitrag zur Kenntnis der palaearktischen Cantharidae, Phengodidae und Malachiidae (Coleoptera) // Entomologica Basiliensia. Vol.4. P.327-346.

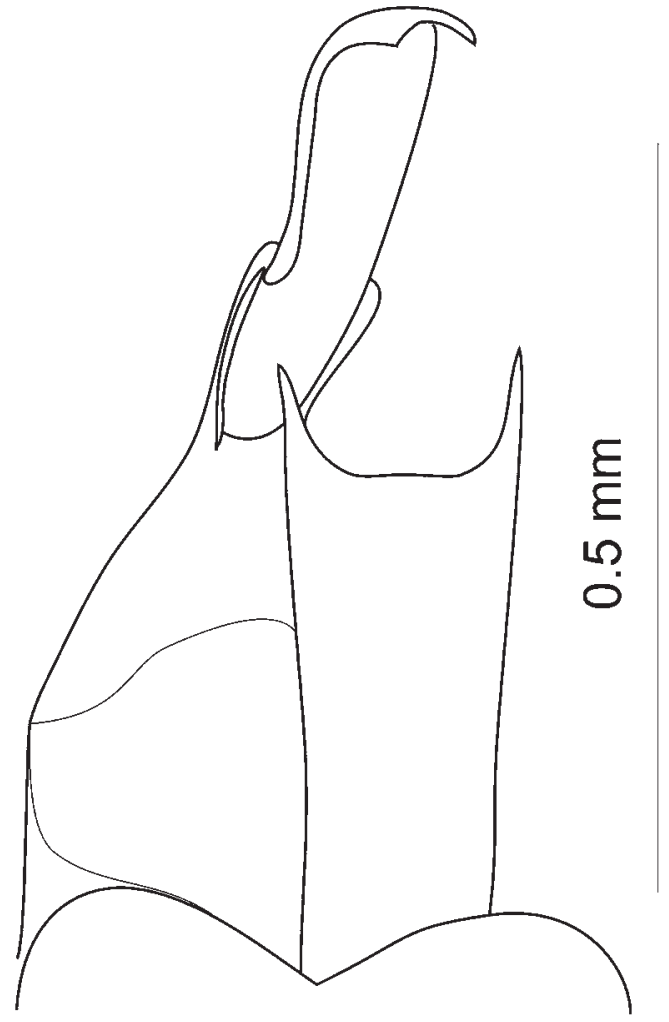

Fig. 3.Terminal abdominal segments of Malthodes perkovskyi sp.n., holotype male, ventrally.

Рис. 3. Вершинные сегменты брюшка Malthodes perkovskyi sp.n., голотип, самец, снизу. 